\title{
Cotidiano do enfermeiro frente ao paciente em cuidados paliativos na terminalidade em enfermarias
}

\author{
Nurse's daily life facing the patient in palliative care in terminality in wards \\ La vida diaria del enfermero ante el paciente en cuidados paliativos en terminalidad en salas
}

Recebido: 14/11/2021 | Revisado: 23/11/2021 | Aceito: 26/11/2021 | Publicado: 08/12/2021

\author{
Elizabeth Pimentel da Silva \\ ORCID: https://orcid.org/0000-0002-4016-8786 \\ Universidade Federal do Rio de Janeiro, Brasil \\ E-mail: elizabethpimente1030372@gmail.com \\ Rafael Esteves Frutuoso \\ ORCID: https://orcid.org/0000-0003-2044-9043 \\ Universidade Federal do Rio de Janeiro, Brasil \\ E-mail: resteves20@yahoo.com.br \\ Cristiane Maria Amorim Costa \\ ORCID: https://orcid.org/0000-0003-1089-2092 \\ Universidade do Estado do Rio de Janeiro, Brasil \\ E-mail: cmacosta1964@gmail.com
}

\begin{abstract}
Resumo
Objetivo: Compreender o cotidiano do enfermeiro frente à assistência ao paciente em cuidados paliativos na terminalidade da vida em enfermarias. Para isso, foram analisados pontos facilitadores e limitadores, e as propostas para otimizar o cuidado na finitude da vida. Metodologia: Pesquisa qualitativa, descritiva e exploratória, realizada com 14 enfermeiras de unidades abertas de internação em um hospital universitário do município do Rio de Janeiro entre agosto e novembro de 2020. Para a coleta de dados, após aprovação pelo Comitê de Ética em Pesquisa, foi utilizada a entrevista semiestruturada e no tratamento dos dados, a análise de conteúdo de Laurence Bardin. Resultados: $\mathrm{Na}$ análise emergiram três categorias: "Fatores facilitadores para assistência das enfermeiras em cuidados paliativos na terminalidade", "Fatores limitadores para assistência das enfermeiras em cuidados paliativos na terminalidade" e "Propostas das enfermeiras para melhoria da assistência em cuidados paliativos na terminalidade". As dificuldades apresentadas foram falta de educação continuada, trabalho em equipe, rotinas e dificuldade em lidar com a morte, além da epidemia por covid-19. Sugeriram-se propostas de capacitação e suporte emocional para a equipe e criação de setor específico. Conclusão: Os relatos identificam um ambiente que não incentiva o exercício da autonomia. Como limitações, ressaltam-se a necessidade de estudos na área pela perspectiva brasileira - desde a sua implantação no país até problemas de pesquisa prementes - e a visibilidade necessária a esses concernidos sob uma perspectiva biopolítica.
\end{abstract}

Palavras-chave: Enfermagem; Cuidados paliativos; Cuidados paliativos na terminalidade da vida; Enfermagem de cuidados paliativos na terminalidade da vida.

\begin{abstract}
Objective: To understand the daily routine of nurses in terms of patient care in palliative care at the end of life in wards. For this, facilitating and limiting points were analyzed, as well as proposals to optimize care in the finiteness of life. Methodology: Qualitative, descriptive and exploratory research, carried out with 14 nurses from open inpatient units at a university hospital in the city of Rio de Janeiro between August and November 2020. For data collection, after approval by the Research Ethics Committee, a semi-structured interview was used and, in the data treatment, Laurence Bardin's content analysis was used. Results: Three categories emerged in the analysis: "Facilitating factors for the assistance of nurses in palliative care in the terminal", "Limiting factors for the assistance of nurses in palliative care in the terminal" and "Nurses' proposals to improve the assistance in palliative care in the terminal". The difficulties presented were lack of continuing education, teamwork, routines and difficulty in dealing with death, in addition to the epidemic caused by covid-19. Proposals for training and emotional support for the team and creation of a specific sector were suggested. Conclusion: The reports identify an environment that does not encourage the exercise of autonomy. As limitations, the need for studies in the area from the Brazilian perspective are highlighted - from its implementation in the country to pressing research problems - and the necessary visibility for those concerned from a biopolitical perspective.
\end{abstract}

Keywords: Nursing; Palliative care; Hospice care; Hospice and palliative care nursing. 


\begin{abstract}
Resumen
Objetivo: Comprender la rutina diaria del enfermero en el cuidado del paciente en cuidados paliativos al final de la vida en las salas. Se analizaron puntos facilitadores y limitantes, así como propuestas para optimizar el cuidado en la finitud de la vida. Metodología: Investigación cualitativa, descriptiva y exploratoria, realizada con 14 enfermeras de unidades abiertas de internación de un hospital universitario de la ciudad de Rio de Janeiro entre agosto y noviembre de 2020. En la recolección de datos, previa aprobación del Comité de Ética en Investigación, se utilizó la entrevista semiestructurada y en el tratamiento de datos, el análisis de contenido de Laurence Bardin. Resultados: Surgieron tres categorías en el análisis: "Factores facilitadores para la asistencia de enfermeras en cuidados paliativos en la terminal", "Factores limitantes para la asistencia de enfermeras en cuidados paliativos en la terminal" y "Propuestas de enfermeras para mejorar la asistencia en cuidados paliativos en la terminal". Las dificultades presentadas fueron la falta de formación continua, el trabajo en equipo, las rutinas y la dificultad para afrontar la muerte, además de la epidemia provocada por el covid-19. Se sugirieron propuestas de formación y apoyo emocional al equipo y creación de un sector específico. Conclusión: Se identificó un entorno que no incentiva el ejercicio de la autonomía. Como limitaciones, se destaca la necesidad de estudios en el área desde la perspectiva brasileña - desde la implementación en el país hasta problemas de investigación urgentes - y la visibilidad necesaria para los interesados desde una perspectiva biopolítica.

Palabras clave: Enfermería; Cuidados paliativos; Cuidados paliativos al final de la vida; Enfermería de cuidados paliativos al final de la vida.
\end{abstract}

\title{
1. Introdução
}

As transformações no padrão demográfico do Brasil apontam que o segmento da população que mais crescerá nas próximas décadas será o de idosos (Instituto Brasileiro de Geografia e Estatística, 2015). Este crescente no processo de senilidade da população tem levado a um aumento dos casos de câncer e outras doenças crônicas. Acrescenta-se que o avanço tecnológico atual, aliado a novos tratamentos, transformou muitas doenças, antes fatais, em crônicas, prolongando a expectativa de vida dos portadores.

Considerando as análises históricas sobre o processo da morte no Ocidente, observa-se que, paulatinamente, este fenômeno transferiu-se do ambiente familiar, público, para uma esfera privada, hospitalar (Ariés, 2017). Cabe destacar também que, em virtude dos novos arranjos familiares, não é possível contar com membros desse grupo que possam disponibilizar tempo, dedicação e conhecimento para estar ao lado do indivíduo na terminalidade no domicílio (mudança na dinâmica relacionada à força de trabalho).

Aliado a isso, a atenção em casa para esse perfil de assistência requer recursos financeiros, não só para compra de insumos e assistência técnica, mas para a organização de um espaço físico adequado ao bem-estar do paciente, o que acarretaria custos. Há ainda que se considerar a mobilidade e o acesso em domicílios menores ou localizados em áreas de difícil trânsito, muitas vezes tornando inviável a manutenção do sujeito adoecido em seu lar.

A dificuldade das famílias em conversar sobre as atitudes a serem tomadas em caso de finitude e morte também se reflete nesse momento. Sem saber previamente quais seriam os desejos do indivíduo em situações ameaçadoras da vida, cabe aos familiares oferecer "tudo" que seria possível, na tentativa de ajudar/salvar o ente querido. E qual seria o melhor local possível para isso, na ótica desses familiares, que não o hospital?

Ante o exposto, os pacientes que se encontram "fora de possibilidades terapêuticas" tendem a adentrar ambientes hospitalares, recebendo por vezes cuidados inapropriados que objetivando o foco curativo, sob métodos invasivos e uso de alta tecnologia, sujeitos à distanásia.

Sem a possibilidade de terapêutica, todo o investimento se afigura inútil, já que ele não é considerado um paciente "curável”, com possibilidade de reagir ao tratamento. A partir desse ponto, o paciente torna-se um leito destituído de nome, sexo, da sua condição clínica e história de vida, restando-lhe aguardar o momento do óbito. Não há espaço e tempo para sua biografia; ao contrário da assistência paliativa, em que ele seria enxergado na sua singularidade, abarcando não apenas a parte física, mas também a psicológica, familiar, espiritual e social.

E então, desse modo, o “indesejado" passa a ser invisível, pois este indivíduo incomoda e causa desconforto à equipe 
de saúde no âmbito hospitalar. Ao contrário da intervenção distanásica do Centro de Tratamento Intensivo (CTI), o paciente internado nas enfermarias que adquiriram o selo dos cuidados paliativos em um hospital voltado para a cura se submete ao não cuidado ou a um cuidado aquém das suas necessidades, ficando a equipe, e dentro desta o enfermeiro, com sentimentos contraditórios e sujeitos à impotência em uma assistência assertiva.

Sendo assim, foi traçado como objetivo discutir junto aos enfermeiros a aplicabilidade dos cuidados paliativos em enfermarias, destacando os fatores facilitadores e limitadores da assistência e propondo medidas que possam otimizar um cuidado digno na finitude da vida).

\section{Metodologia}

Tratou-se de pesquisa descritiva e exploratória com abordagem qualitativa devido à natureza do objeto de estudo, já que esta valoriza tais elementos, além de apresentar a inquietação com um tipo de realidade não quantificável (Minayo, 2013). O cenário foi um hospital universitário localizado no município do Rio de Janeiro. Quanto aos participantes do estudo, foram selecionados 14 enfermeiros que estavam lotados em unidades abertas de Internação (Setores de Clínica Médica e de Clínica Cirúrgica) ou supervisores. Os critérios de exclusão foram enfermeiros que trabalhassem em unidades de cuidados intensivos ou "fechados" ou, ainda, aqueles que trabalhassem em enfermarias, mas não fossem plantonistas ou não atuassem na assistência direta ao paciente. Para a técnica de coleta de dados, foi utilizada a entrevista semiestruturada, que foi aplicada entre agosto e novembro de 2020.

Como fator limitador deste estudo, sublinham-se as readequações sofridas pelo hospital devido à pandemia por covid19, que veio afligir os profissionais e a população assistida.

No que se refere à análise dos dados, o material obtido nas entrevistas foi submetido à análise de conteúdo de acordo com os preceitos de Laurence Bardin (2011). A classificação resultou em categorias temáticas de análise, que fizeram a articulação dos dados com os conceitos discutidos na pesquisa.

Quanto aos aspectos éticos e legais, vale ressaltar que o estudo foi inscrito na Plataforma Brasil e submetido ao Comitê de Ética em Pesquisa da instituição onde o trabalho foi desenvolvido.

\section{Resultados e Discussão}

Ao final da sistematização, chegou-se a três categorias - "Fatores facilitadores para assistência das enfermeiras em cuidados paliativos na terminalidade", "Fatores limitadores para assistência das enfermeiras em cuidados paliativos na terminalidade" e "Propostas das enfermeiras para melhoria da assistência em cuidados paliativos na terminalidade".

\section{Fatores facilitadores para assistência das enfermeiras em cuidados paliativos na terminalidade}

Observa-se que os pontos facilitadores dos cuidados podem ser avaliados em torno de três elementos: aqueles pertinentes à equipe, ou seja, ao profissional; relacionados ao paciente, incluindo principalmente o papel benéfico da família nesse momento delicado; e fatores institucionais, que levam em consideração a estrutura propriamente dita do hospital.

Vale ressaltar que o fato de a pesquisa ter sido desenvolvida com enfermeiras levou a muitas falas sobre o cuidado em si, o qual faz parte da lógica do cuidado paliativo, mas antes é uma condição fundamental do cotidiano da enfermagem. Estão elencadas algumas falas relevantes nesse sentido:

Na verdade, tem o cuidado, o cuidado sempre vai estar ali, então de repente pro médico pode não ter o que fazer, mas pra gente sempre tem o que fazer, cuidados de enfermagem. (E 10)

[...] eu acho que ele ainda merece ser tratado, se ele tiver acamado receber os cuidados que ele precisa, cuidar, 
virar, de ter conforto, medicação, porque às vezes não vai ter muito tempo, mas acho assim, cuidado que eu como pessoa física ali com ele posso fazer, eu tento fazer o máximo possível. (E 14)

O norte da ciência da enfermagem é o cuidado, o conhecimento e sua evolução, bem como a estrutura teórica e prática. Deste modo, o cuidado é construído a partir do conhecimento científico e empírico do enfermeiro, da cultura e das crenças de quem cuida, daquele que é submetido ao cuidado, de quem o acompanha, da instituição e do ambiente em que estes atores estão inseridos (Rocha et al., 2008).

Ainda na perspectiva do olhar diferenciado da enfermagem e das virtudes inseridas no contexto dos modos de cuidar, surgiram relatos que tratam da importância do acolhimento.

Eu acredito muito no acolhimento, acolher aquele paciente, porque ele tem uma família também, ele tem mãe, ele tem pai, ele é um querido de alguém. (E 01)

É o acolher do paciente. É o acolher em todos os sentidos. (E 02)

O acolhimento é uma tecnologia leve que precisa ser utilizada na implantação das práticas de saúde. A busca do profissional deve acontecer no sentido da qualificação do acolhimento apoiado na teoria do cuidado de enfermagem, tratando o paciente de modo humanizado, situando-o como sujeito e participante desse processo (Costa et al., 2016). Seguem as autoras na defesa de que a utilização de tecnologias leves, entendidas dentro das relações humanas, deve ser central na prática de enfermagem, dentro de uma perspectiva para que o objeto do cuidado seja o indivíduo e não a doença.

Sendo assim, tudo indica que os princípios dos cuidados paliativos já estão arraigados na própria ontologia da enfermagem, de modo que, após a graduação, é esperado um profundo conhecimento teórico e prático sobre cuidados ao indivíduo em toda a sua integralidade.

A aceitação da morte, apesar de tema de difícil abordagem na sociedade e no ambiente hospitalar-curativo, foi mencionada por uma das entrevistadas como fator facilitador:

Isso pra mim, pessoalmente, é um facilitador. Eu acho que eu tenho facilidade de enxergar essa situação. Eu aceito bem o processo de morte, eu vejo assim equiparando com o processo de nascimento. Quando a gente perpassa lá a maternidade, a gente vivencia o ser humano em todas as etapas de vida, desde o nascimento até a morte, então desde que eu comecei a lidar com paciente que está no processo de morte, eu comecei a ver dessa maneira, com a mesma naturalidade que as pessoas nascem, as pessoas morrem. E faz parte. O meu papel aqui é tornar isso melhor, é um processo natural que vai acontecer. (E 07)

Nessa busca por aceitação, ocorre também um processo de transformação e ressignificação desse momento, observado no relato de quem, ao lidar com a terminalidade, mesmo reconhecendo as dificuldades envolvidas, percebe essa mudança no olhar.

[...] porque para a gente é difícil paliativar um paciente, é difícil saber que o paciente tá paliado, porque a gente quer que o paciente viva. Para a gente é uma derrota de certa forma, a gente sabe que a gente não consegue fazer tudo, mas na vida ninguém consegue mesmo fazer tudo, isso é normal. (E 09)

Estudos de Bifulco e Iochida (2009) indicam que a compreensão e a aceitação da morte como parte da vida permitem que a assistência ao paciente paliativo seja encarada como consequência de estar vivo e não como um fracasso do cuidado. Destacam ainda que a própria finitude pode favorecer o lidar melhor com a vida do outro, como se verificou nesse último relato.

A esse respeito, a espiritualidade/religiosidade interfere no cuidado prestado como um facilitador ao lidar com o processo de finitude. 
[...] então eu acho que quando a gente entende isso como processo natural e aceita que isso faz parte do nosso cuidado, a coisa fica mais fácil, falo: "gente, eu até por ser católica, eu faço uma oração ali”, preparo o corpo e está tudo certo. (E 07)

De acordo com Tavares et al. (2018), os enfermeiros tendem a identificar e entender singularidades contidas nos termos da espiritualidade e religiosidade, compreendendo a ligação entre eles. A tendência é que esses conceitos sejam influenciados pela própria vivência de espiritualidade e religiosidade do profissional.

Desse modo, o cuidado de si e do outro engloba aspectos espirituais e religiosos que ajudam a reduzir os impactos causados pela internação; esse cotidiano favorece o cuidado do outro e também do enfermeiro que cuida; ou seja, um maior grau de espiritualidade e religiosidade dos profissionais reflete um maior conhecimento sobre como esses conceitos interferem no processo de hospitalização (Tavares et al., 2018).

As características relatadas anteriormente, que auxiliam no processo de enfrentamento da morte, mostram como a enfermeira poderia facilitar o processo da terminalidade por meio de sua atuação.

Claro, não vai ser um tempo que vai atrapalhar nossa assistência, nossos cuidados, mas o máximo de tempo que eu puder deixar eu vou deixar. Eu acho que a gente tem que se colocar à disposição da família também. A gente não pode resolver o problema, mas a gente pode se colocar à disposição para o que for necessário e o que for possível. (E 07)

Segundo Menezes (2004, p. 95), a "realização em CP [cuidados paliativos] consiste no controle adequado do processo de morrer, através de uma assistência à totalidade bio-psico-social-espiritual do doente e de seus familiares". O profissional que propicia essa atenção ao paciente antes negligenciado adquire uma formação e habilitação para cuidar do enfermo no período final de sua vida; o produto final seria "uma boa morte".

No tocante às facilidades inerentes ao paciente, cabe ressaltar que, embora o processo da terminalidade envolva uma necessidade de grandes adaptações por parte dele e da família, foram encontrados depoimentos que mostram o quanto a aceitação desse processo e a presença da família são facilitadores na finitude.

Acho que a presença da família, não voltada somente para a questão de assistência ao paciente, mas em questão acho que pensando mais por um lado afetivo, emocional, acho que a presença do familiar é muito importante. (E 05)

A família tem caráter central dentro da sociedade, sendo a rede social primária de apoio aos sujeitos e tendo responsabilidade na formação, no desenvolvimento e na socialização dos indivíduos. Nesse diapasão, as equipes poderiam auxiliar pacientes e suas famílias no enfrentamento e aceitação em condições de terminalidade por meio de um cuidado que reduza o sofrimento não só físico, mas também psicossocial e espiritual, com uma comunicação honesta, incentivando a autonomia e proporcionando dignidade aos concernidos (Espíndola et al., 2018).

No que se refere aos facilitadores institucionais, emergiram falas mostrando que o fato de os profissionais trabalharem em um hospital-escola possivelmente favorece a busca pela ciência, pelo conhecimento, e isso tende a se refletir em todas as áreas, inclusive em cuidados paliativos.

Eu acho que facilita que aqui é um hospital universitário, então assim, tudo que é uma proposta nova, que é uma proposta que está em estudo, aqui é mais fácil de implementar, porque as pessoas têm uma cabeça mais voltada para a ciência, mais para o estudo. (E 04)

[...] eu acho que a estrutura do hospital, acho que a assistência que a gente tem, a qualificação dos profissionais, acho que ajuda sim. (E 05) 
No Brasil, os hospitais universitários são vistos como polos na formação de recursos humanos e tecnológicos, ao passo que também são prestadores de serviço para a população, elaborando protocolos técnicos e oferecendo programas de educação continuada, participando na atualização técnica dos profissionais de saúde (Brasil, 2012 citado por Araújo \& Leta, 2014).

Institucionalmente, há os que veem a condição do paciente hospitalizado como um fator facilitador para um melhor enfrentamento da finitude.

[...] a diferença de um paciente que morre em qualquer outro lugar ou morre num ambiente hospitalar é esse, aqui ele tem que ter suporte, ele tem que ter assistência medicamentosa, psicológica, um ambiente favorável. (E7)

Segundo Kruse et al. (2007), a internação na terminalidade é necessária quando é impossível para as famílias manterem o paciente em casa por razões logísticas ou financeiras, sobretudo quando há comprometimento na autonomia e independência do enfermo, quando não conseguem suportar a carga de sofrimento ao acompanhar o ente querido ou quando não há disponibilidade de recursos especializados necessários.

Tal constatação leva a crer que, assim como se pode importar modelos europeus ou americanos de pesquisas sobre obstinação em Unidade de Terapia Intensiva (UTI), fenômeno semelhante talvez esteja acontecendo com a necessidade imperiosa de que o paciente busque a morte em casa. Na atual conjuntura, com as políticas de regulação da vida e da morte, a satisfação de quais atores sociais está sendo atendida? Talvez o enfermo, a família ou o profissional possam optar pela morte hospitalar bem assistida, e tal situação deve ser considerada.

Menezes (2004) justifica essa consideração lembrando que os aspectos socioeconômicos dos pacientes, que interferem nas relações de moradia, são extremamente complexos e não dependem da atuação da equipe; a importação de um modelo de cuidados paliativos proveniente de países com condições socioeconômicas e culturais, noções de indivíduo, direitos e cidadania muito distintas das brasileiras, limita significativamente que o processo de terminalidade ocorra no domicílio.

Assim, mesmo que o hospital inicialmente possa ser considerado um ambiente ameaçador, onde o doente estará subjugado ao controle da equipe e da tecnologia, existe o risco de a casa deformar-se, em uma tentativa de se adaptar à morte anunciada (Azevedo, 2020).

Tais ponderações são colocadas para que não se descarte a hospitalização em situações de fim de vida, como foi citado no relato anterior, demonstrando que pode existir uma boa argumentação dentro desse discurso.

Diante disso, percebe-se que os fatores facilitadores citados pelas participantes da pesquisa vão ao encontro das concepções idealizadas do cuidado paliativo.

\section{Fatores limitadores para assistência das enfermeiras em cuidados paliativos na terminalidade}

A análise das entrevistas mostrou os desafios encontrados no cotidiano pelas enfermeiras que assistem os pacientes na terminalidade. Essas limitações se dão em três frentes - aquelas relacionadas ao próprio profissional de enfermagem ou de outras profissões; as de caráter técnico-científico ou ainda, relativas ao difícil enfrentamento da morte; e as referentes ao paciente com relação à autonomia ou família, bem como os que estão associados ao processo de finitude. Finalmente, foi revelado que problemas institucionais de estrutura, recursos e processos de trabalho, incluindo oferecimento de mecanismos de suporte emocional/psicológico, também constituem entraves para uma assistência de qualidade.

Primeiro será abordada a questão das limitações da própria equipe de saúde, na qual se observa uma grande dificuldade no enfrentamento do sofrimento e da morte do outro (paciente):

[...] eu cheguei a pensar que eu não fosse aguentar ficar ali do lado do paciente paliativo, e pensando: "ele vai 
agora, eu não vou aguentar”, mas não, eu tava ali, fiquei ali, dava vontade até de chorar [...] e eu pedia a Deus, meu Deus não faça isso, não leva. (E 01)

[...] a gente continua com aquele sofrimento de ver aquele paciente, mas a gente tenta se manter meio que inerte, sem se aprofundar. Eu percebo e tento fingir que não estou percebendo, mas eu me sinto mal, eu não consigo assim fingir, eu choro, isso me dói... (E 02 )

[...] apavora mais o profissional do que o paciente, sim. Até o próprio profissional, às vezes, eu já vi, não aqui, mas em outras instituições, falar assim: "ih, tá tomando morfina, esse ai não vai demorar muito e vai morrer". E não é assim, entendeu? Então eu fui buscar estudar pra tentar, como eu posso dizer, não ter esse medo, também tinha um verdadeiro pavor... (E 08$)$

[...] um exemplo é o paciente que eu sou muito apegada, quando ele está morrendo eu quero distância, não quero ficar, porque assim, eu acho que ele não precisa de mais um pra chorar... (E 09)

O doente e sua família enxergam no profissional alguém que tem certo controle sobre o processo saúde-doença, com capacidade para reduzir sentimentos de fragilidade e sofrimento. Projetam nesse agente uma relação verdadeira, empática, disponível e estável. Porém, diante do fim de vida, o paciente e sua família podem experimentar sensação de insegurança, exigindo mais do profissional, provocando um aumento na carga física e emocional que pode interferir na assistência, principalmente se ele mesmo não nota esse fenômeno (Milberg et al., 2012).

Torna-se imprescindível o profissional perceber os sentimentos que o cuidado e suas relações despertam em si próprio e notar sentimentos como raiva, prazer, satisfação em cuidar, ou sentimentos contrários. Uma assistência satisfatória requer inteligência emocional e conhecimento de si. Nesse sentido, as instituições devem incluir capacitações não somente no âmbito técnico, mas também na esfera emocional, incentivando o autoconhecimento e a reflexão sobre a própria trajetória de vida (Kovács, 2003).

Essas dificuldades refletem-se também na projeção da própria morte (a morte de si mesmo) ao lidar com a finitude do paciente.

[...] essa coisa de fim de vida eu acho bem complicado, a gente tá aqui com saúde, daqui a pouco sai de um plantão, a gente não sabe o dia de amanhã... (E 01)

[...] mas eu, eu sinto e eu chego em casa e lembro de situações, mas eu não gosto de comentar dentro da minha casa, $e$ às vezes eu sofro com isso, porque são situações que a gente percebe - será que um dia eu vou estar nessa situação? Será que isso vai acontecer comigo? (E 02)

[...] não sei se é porque eu também tenho muito medo e falo muito disso de ficar sozinho [...] Já teve paciente que eu falei Deus me livre eu ficar ali, eu venho pedindo a Deus, Senhor, não me deixa ficar ali com ele morrendo não, porque eu não vou suportar, não vou suportar, e minha mãe fica super preocupada com isso porque quando eu chego, parece que eu vou morrer, a sensação é essa. (E 09)

Na tentativa de explicar tal fenômeno, Marreiro (2014) relembra que o homem é o único ser que tem consciência da sua morte, vindo a temê-la, pois a associa à perda da sua individualidade, à desintegração de tudo aquilo que constrói e legitima a existência de si. Esse tema também é bastante explorado por Heidegger (1997), que conceitua a morte, em uma perspectiva ontológica da análise existencial do homem, como fim da presença, uma vez que a morte é e está em seu ser-para o fim.

Almeida et al. (2014), trazendo a reflexão para a realidade da enfermagem, revelam que o enfermeiro experimenta em muitos momentos a tristeza do cuidar ao lidar com a terminalidade da vida, pois a morte é uma realidade cotidiana, que provoca sofrimento e angústia. Para realizar o cuidado humanizado, o enfermeiro dispõe de si mesmo, sendo fundamental transcender a si próprio para ser capaz de fornecer a assistência. 
As autoras reconhecem a necessidade de o enfermeiro estar preparado para lidar com a terminalidade e a morte e não se negar ao cuidado, ajudando o doente no enfrentamento da sua finitude. Para isso, é indispensável encontrar o sentido do seu próprio ser e reconhecer que a morte é um processo inevitável, estando desde o princípio o ser humano predeterminado para o fim (Almeida et al., 2014).

A questão da habilidade ou da identificação com a clientela também foi referida, como se houvesse a necessidade de uma aptidão prévia.

[...] as pessoas que estariam ali, elas teriam uma habilidade, acho que, da percepção, o refletir muito da questão de como eu vou lidar... (E 02)

Ah, eu acho que o ideal seria ter uma equipe que se identificasse com esse perfil de paciente, que eu acho essencial, quando você se identifica você tem outra visão; tendo outra visão, você tem um trabalho talvez um pouco mais diferente. (E 13)

Em sua tese de doutorado, Rodrigues (2009), ao acompanhar uma equipe de cuidados paliativos, analisou depoimentos afirmando que, para trabalhar com tal clientela, há necessidade de um perfil com características tais como: ter sensibilidade, ser paciente, ter compaixão e respeito pelo outro, ser comunicativo, trabalhar em equipe, gostar de trabalhar com paciente na fase final de vida e saber lidar com a morte (sua e do outro). A autora orienta sobre a importância do enfoque nas atitudes e competências psicossociais e espirituais do indivíduo, para além da dimensão técnica.

É importante salientar que, muitas vezes, as limitações dos próprios pacientes são as que dificultam a assistência. Essas barreiras, apresentadas a seguir, não estão relacionadas ao profissional, nem seriam impostas pela instituição, mas são fruto da cultura, do meio social, ou mesmo da organização familiar do enfermo.

A dificuldade principal refere-se à forma como o paciente encara o processo de fim de vida. Frequentemente, o enfermeiro lida com usuários que não tiveram acesso à rede básica no início do diagnóstico ou não puderam usufruir de uma rede de assistência efetiva focada nos cuidados paliativos na atenção primária. Tais fenômenos provocam uma inconstância no enfrentamento das perdas significativas ao longo dessa jornada, podendo gerar a não aceitação, ainda que no momento derradeiro, como exemplificam os relatos.

Tem coisas que a gente observa, como a postura do paciente mediante a doença influencia no como ele vai progredir, em como vai ser o prognóstico dele. Eu já vi isso na prática, na assistência, você vê paciente assim muito bem-humorado, às vezes com condições gravíssimas, mas que ele tem uma, digamos assim, uma boa evolução dentro de uma limitação, diferente de pacientes que, às vezes, não tinham um prognóstico tão ruim, mas eles afundam por conta mesmo de uma questão mental, enfim, de não aceitação. (E 07)

\section{[...] mas assim o medo da solidão que eles têm, da gente estar perto, mais próximo... (E 09)}

Kübler-Ross (2008) sistematizou os cinco estágios pelo qual o doente transita antes da aceitação de sua morte. São eles: negação, raiva, barganha, depressão e aceitação. Essas fases podem não se suceder nessa ordem e não é obrigatório que o paciente passe por todas elas.

Aliado a essa circunstância de como o paciente encara o processo de morrer, influenciando também o núcleo familiar, paira o fato de que a sociedade trata como tabu as discussões sobre a morte. Isso amplia a aura de angústia e sofrimento do paciente nesse momento findo, exacerbando a dificuldade de aceitação do processo de fim de vida pelos parentes, como demonstrado a seguir:

Porque é o que eu estou te falando, o cuidado de fim de vida ele mexe muito com a família também, porque antes a gente colocava simplesmente o biombo e deixava falecer, a gente não deixava a família do lado. Hoje como tem 
família junto com aquele paciente, tem que trabalhar a família junto com aquele paciente terminal. E é angustiante tanto pra ele quanto para a família... (E 11)

Para mim, uma morte digna é o paciente não sentir dor, familiar estar presente desde que ele tenha apoio emocional para aceitar, aceitação - a verdade é essa, porque tem familiar que não aceita e aí fica mais difícil... (E 13)

Esses relatos encontram ancoradouro nos escritos de Ariès (2017), que acompanhou o trajeto histórico do processo de morrer. $\mathrm{O}$ autor descreve que, desde a Idade Média até a Idade Contemporânea, a sociedade passou da morte domada até a morte interdita, transitando também pela "morte de si mesmo" e pelo reconhecimento da morte do outro. Essa reflexão histórica permite a avaliação de como essas transformações sociais acerca da morte podem ser percebidas, o que ajuda a explicar o processo de morrer no núcleo social do paciente.

No século XX, ocorreu a consolidação dessa atitude diante da morte, havendo o deslocamento para os hospitais. Para Kübler-Ross (2008), morrer converteu-se num ato solitário e impessoal, em que o enfermo é retirado do ambiente domiciliar e depositado sobre um leito hospitalar, onde, em regra, morrerá sozinho ou acompanhado por máquinas e estranhos vestidos de branco.

O relato seguinte demonstra como, em alguns momentos, a família parece compreender o processo pelo qual o paciente está passando, mas por não saber lidar com essas emoções, acaba por se distanciar, dificultando as relações.

[...] conheci uma pessoa lá fora que está passando por um câncer, tá nesse período de cuidados, só que a família está com medo, com medo de se mostrar fraca diante da pessoa que está doente, não vai, não quer ir para as consultas, não quer estar perto com medo de desmoronar e ser pior pra paciente. Então, eu vejo esse outro lado que eu não estava vendo antes, eu olhava e falava: "ah, mas a família não tá aqui", e tal, só que agora eu estou vendo esse outro lado, que a família tem esse receio de ao invés de ajudar, atrapalhar. (E 01)

Nesse sentido, uma das explicações para o fenômeno vai ao encontro do que Azevedo (2020) apresenta em seu artigo, sinalizando que familiares que cuidam de idosos dependentes têm maior prevalência de doenças crônicas, isolamento social e depressão do que pessoas fora dessa situação. De acordo com a proximidade da morte, a sobrecarga para os familiares pode ser intolerável. O autor enfatiza ainda que o desgaste econômico da família, derivado do cuidado ao enfermo, deve ser considerado. Assim, apesar de reconhecer que o cuidado familiar tem potencial de identidade e satisfação, conclui que cada família protagonizará aspectos positivos e negativos, conforme seus recursos físicos, materiais e emocionais, não existindo, portanto, um cuidado ideal, mas o melhor cuidado possível por parte desse núcleo.

Reigada et al. (2014) indicam que uma família pode adotar um comportamento dominado por mecanismos de defesa, por não ter podido realizar um amadurecimento adequado e uma análise da realidade antes da iminência da morte.

A ausência dos familiares também pode ocorrer devido a certos arranjos sociais, uma vez que pode não haver um membro com disponibilidade para estar ao lado do doente, ou pode dar-se o caso de abandono por situações não totalmente compreensíveis para a equipe de saúde; mas o fato é que essa ausência tem impacto direto na assistência e no bem-estar do paciente:

[...] porque pelo o que eu vejo aqui, a gente tem vários em cuidado paliativo e a maioria, assim, você não vê a família ali com eles, e eu acho que isso faz muita falta, pra dar um incentivo, falar uma palavra de carinho, de conforto pra eles... (E O1)

[...] a gente vê tantos pacientes que não têm família, eu já vi paciente aqui que não tinha nenhuma família, e ele estava ali morrendo e a gente teve que fazer esse papel. (E 09)

Dissertando sobre a obra de Kübler-Ross, Kovàcs (2003, p. 76) comenta que deve ser muito angustiante para um 
doente perceber que os que estão ao seu redor desistiram dele como pessoa que tem esperança de sobreviver ou realizar projetos. Nesse caso, é como se o condenassem à morte pelo desinvestimento afetivo.

O núcleo familiar desempenha um papel social fundamental, além de ser uma fonte de apoio social, pois sua presença gera sentimento de cuidado, segurança e dignidade, e faz com que o indivíduo acometido por uma doença grave não se sinta abandonado, em regra, em um leito hospitalar (Bautista-Rodríguez et al., 2016; Oliveira-Cardoso \& Santos, 2017).

Ainda com relação aos determinantes do paciente, cabe salientar que a falta do exercício da autonomia, aliada ao paternalismo dos profissionais, limita a otimização da assistência prestada. Os pacientes não têm o hábito de participar ativamente das suas escolhas, tampouco seus familiares, ficando as questões de fim de vida a cargo dos profissionais de saúde, que não sabem quais seriam os desejos e anseios da sua clientela, tais como nos relatos seguintes:

Pacientes que têm condição ainda de verbalizar o que querem, o desejo que têm, tem que ser viabilizado: "ah, eu quero ver meu cachorro antes de morrer", traz o cachorro... Gente, hoje em dia com cuidado, com cautela, a gente faz qualquer coisa. (E 07)

Ver o desejo dele e tentar dentro daquilo ali fazer algo que pra ele seja interessante, que ele goste [...] e ele ter a condição de ter naquele momento aquilo que ele quer, que é direito dele. (E12)

Beauchamp e Childress (2002) defendem que a autonomia se refere ao governo pessoal do eu que é livre tanto de interferências controladoras por parte dos outros como de limitações próprias. Os relatos acima apontam a necessidade de considerar os desejos e vontades do enfermo; nesse sentido, os autores descrevem que ser autônomo não significa necessariamente ser respeitado como agente autônomo. Respeitar esse agente se caracteriza pelo reconhecimento do direito desse indivíduo de ter opiniões, fazer escolhas e ter suas ações ancoradas em seus próprios valores e crenças. Para tanto, são necessários uma ação respeitosa e o dever de manter a capacidade do outro de realizar tais feitos.

Segundo Menezes (2004), o movimento paliativista brasileiro surgiu de iniciativas relativas ao aparato médico, diferente da forma como ocorreu nos Estados Unidos da América e na Inglaterra. No Brasil, a reivindicação pela autonomia não adveio de meios sociais amplos e as equipes têm dificuldade de colocar em prática "um modelo importado de países com concepções e valores sobre individualidade e família tão diferentes dos nossos” (p. 154).

Ademais, no país há uma cultura que não estimula os processos decisórios com autonomia plena, principalmente nas relações com o Estado. A assistência à saúde, com um viés paternalista, também dificulta que o indivíduo hospitalizado tenha seu autogoverno com respeito a vontades, desejos e deliberações.

No que concerne aos fatores institucionais, parece que, para um bom atendimento à clientela em cuidados paliativos, existe a necessidade de treinamento profissional e desenvolvimento de habilidades. Quando perguntados sobre a limitação entre uma assistência almejada e uma assistência real, os entrevistados se referiram à capacitação.

[...] eu acho que teria que favorecer cursos, a formação dos próprios profissionais, e acho que favorecer essa questão da formação mesmo que a gente não tem aqui, as pessoas são colocadas em serviços, mas não tão com uma formação pra aquilo ali, talvez, acho que isso poderia melhorar um pouco a assistência, infelizmente não tem aqui. (E4)

É oferecer embasamento teórico, científico, pra gente conseguir agir nas diversas situações [...] foi preciso eu aprender e orientar a equipe [...] a gente tem que ter a nossa consciência tranquila de que a gente está fazendo um cuidado e que a gente tem respaldo pra realização desse cuidado. (E 09)

Quanto a essa problemática, há de se explorar que, independente da educação permanente ou da educação continuada realizada pelo profissional ou que as unidades de saúde possam fornecer, deve-se atentar para as limitações de primeira instância, que são as lacunas ou distorções advindas da graduação.

Nesse sentido, Oliveira et al. (2011) observam que uma das primeiras disciplinas do curso de enfermagem é a 
Anatomia, utilizando o cadáver como objeto de estudo. Os autores acreditam que o contato com esse "primeiro paciente", por si só, já provocaria uma cisão, pelo fato de ser algo para ver e manusear, mas não para ouvir. Paralelo a isso, tem-se a negação da angústia pela academia, a fragmentação do ensino em pequenas disciplinas, que transformam o corpo em partes destituídas de humanidade, e a falta de abordagem da morte durante o curso.

Após a graduação, já no mercado de trabalho, é aconselhável o desenvolvimento da educação permanente e educação continuada. Com relação à enfermagem, os dois tipos de atividades oferecem aos trabalhadores a possibilidade de atualizar os conhecimentos técnico-científicos, agregar novos saberes e desenvolver consciência crítica sobre o processo de trabalho, estimulando-os a repensarem atitudes e comportamentos, no plano individual e coletivo, na dinâmica da instituição (Ares, 2015).

Portanto, essa deficiência na formação e capacitação não é problema apenas para a equipe de enfermagem, mas se propaga para outros membros, como neste exemplo relacionado à medicina, demonstrando a falta de conhecimento técnicocientífico:

[...] os médicos têm medo de prescrever morfina, quem não sabe atender paliativo tem medo. O clínico geral não vai querer prescrever porque ele acha que o paciente vai fazer depressão respiratória e vai morrer... (E 08)

A respeito do uso da morfina, a regra do duplo efeito, baseada na diferença entre os efeitos visados e os efeitos previstos de uma conduta, é adotada para justificar que um ato com duas consequências previstas, uma boa e uma nociva (como a morte), nem sempre é moralmente proibido caso o efeito nocivo não seja pretendido ou visado (Beauchamp \& Childress, 2002).

Na prática, observa-se que os médicos, por desconhecimento técnico e bioético, receio jurídico, preconceito, ou por falta de supervisão adequada (no caso dos residentes), não prescrevem ou prescrevem de forma inadequada os opioides, não sendo capazes de aliviar a dor do paciente ou causando uma sedação não indicada.

O ensino acadêmico dos cuidados paliativos e da terminalidade, com abordagem de controle rigoroso dos sintomas, associado à educação continuada e permanente, com uma supervisão adequada dos residentes e o apoio de uma equipe interdisciplinar, poderia corrigir tais desvios.

Ainda quanto aos desafios cotidianos que precisam ser enfrentados para uma assistência satisfatória ao paciente, existem as demandas de recursos humanos, não só pela sua escassez, no caso específico da enfermagem, mas devido às barreiras impostas para um trabalho interdisciplinar pelas relações de poder, passando pela falta de apoio emocional/psicológico para esses profissionais.

Foi apresentada nas falas das enfermeiras uma preocupação referente à inadequação quantitativa de profissionais para uma assistência aos pacientes em processo ativo de morte.

[...] a gente tem que estar acolhendo também não só o paciente, mas o familiar também, que muitas vezes, a maioria das vezes, pela dificuldade que nós temos ao nível do quantitativo de profissionais, de ser reduzido, não temos um tempo de poder estar ali junto, então muitas das vezes a gente fica pouco tempo junto ao familiar, conversa um pouquinho, não dá pra ficar dando aquela atenção que deveria dar [...] em um setor de clínica médica, você tem um paciente em cuidado paliativo, ele vai ser tratado como outro paciente qualquer, ele não vai ter nenhuma estratégia, nenhum plano de ação que trabalhe ele de uma forma diferenciada, primeiro que eu não posso colocar um técnico só para aquele doente, então ele vai entrar naquele paciente, fazer o que tem que fazer, sai e vai fazer no outro, ele não vai ficar somente naquele. (E 02)

Para a realidade da enfermagem, reduções no quadro de profissionais significam acúmulo de atividades e sobrecarga de trabalho, ocasionando intensificação laboral, que transparece, num primeiro momento, no desempenho concomitante de 
diferentes funções (Moreira, 2017; Santos, 2012).

Os efeitos desse cenário, tais como a desorganização da ambiência, o excesso de trabalho, o desgaste físico e o sofrimento psicológico, além de levarem à intensificação do trabalho, interferem no desenvolvimento adequado das atividades e impactam a qualidade dos serviços (Dodou et al., 2017; Elias \& Navarro, 2006; Felli, 2012; Mendes, 2007; Moreira, 2017; Santos, 2012).

Quanto a esse tema, o Conselho Federal de Enfermagem publicou a Resolução ${ }^{\circ}$ 543, de 2017, atualizando o cálculo de dimensionamento de profissionais, que preconiza parâmetros mínimos para calcular o quantitativo de profissionais (Conselho Federal de Enfermagem, 2017). Nesse cálculo, está contemplada a classificação dos pacientes, que constitui um parâmetro para a equipe se adequar de forma satisfatória aos cuidados dos pacientes em fim de vida.

Em relação ao trabalho da equipe interdisciplinar, destacaram-se várias problemáticas nos relatos das entrevistadas. Inicialmente, relataram que não há profissionais de todas as categorias necessárias ao trabalho em cuidados paliativos, e, quando há, são em número insuficiente.

Ah, eu acho que teria que ter um acompanhamento psicológico, eu acho que já até tem essas especialidades, mas de ter assim como a gente solicita não, psicologia vem conversar, vem fazer uma reunião com a família, mas eu acho que isso poderia ajudar [...] Isso da psicologia, do serviço social pra tentar envolver mais... (E 01)

[...] se a gente pudesse ter uma copa, a nutrição falou que pode mandar isso pro senhor, o senhor quer, é um desejo dele que muitas das vezes não é assim que funciona... (E 02)

[...] eu acho deveria ter uma interação melhor com a equipe, de trabalhar mais essa interdisciplinaridade entre as várias áreas de conhecimento. (E 04)

[...] tem que ter mais profissionais diretos, tipo assistente social, a gente não tem aqui uma assistente social 24 horas que possa estar fazendo essa ponte com a família, e um psicólogo que pudesse estar fazendo uma ponte também com a família, ter uma equipe multidisciplinar mais ampla nesse sentido, porque aqui no ambiente hospitalar a gente fica muito assim: médico, enfermeiro, técnico. A gente não tem tantos outros profissionais aqui presentes nesses processos... (E 07)

Segundo Baère et al. (2017), a questão de interdisciplinaridade parece não estar bem clara para a equipe de saúde, dificultando a prática e o esclarecimento do conceito. É um termo diferente da multidisciplinaridade, em que ocorre apenas trocas de informações; já da equipe interdisciplinar é esperada a construção de reflexões, discussões e práticas de forma unificada.

O cerne da assistência em cuidados paliativos não é a cura da patologia, mas a assistência integral à pessoa, de modo que nutricionistas, fonoaudiólogos, psicólogos, médicos, enfermeiros, fisioterapeutas, terapeutas ocupacionais, dentistas, assistentes sociais, entre outros profissionais da saúde, estejam em sincronia no cuidado (Academia Nacional de Cuidados Paliativos [ANCP], 2012; Saar \& Trevizan, 2007; Silva, 2015).

Interessantes relatos emergiram mostrando as relações de poder que permeiam as equipes. Algumas participantes fizeram considerações sobre o modelo centrado no médico e a forma como a enfermagem é subjugada no ambiente hospitalar.

[...] acho que a gente tem uma parceria legal com algumas equipes médicas, que notificam quanto antes, mas com outras não. Até que a coisa se torne oficial ou não, a gente vai ter que puxar carrinho, mesmo sabendo que é um final de vida [...] porque a gente fica dependente da decisão médica, da documentação médica, não é um trabalho multidisciplinar, é individual [...] Fica mais na mão do médico. É como se o conhecimento do enfermeiro não pesasse... (E 06)

[...] aqui, pra gente solicitar uma avaliação da psicologia, o médico tem que ver primeiro, mas se eu observei a demanda, então eu acho que é dessa forma, se a gente conseguisse ser mais integrado profissionalmente, serviço social, enfermagem, equipe de saúde como um todo, acho que a gente conseguiria oferecer um melhor cuidado pra esses pacientes. (E 09) 
Gaspar (2017) descreve que a desvalorização dos enfermeiros, especialmente quanto ao seu raciocínio clínico, representa uma barreira para a participação desses profissionais nas tomadas de decisão relativas ao tratamento de saúde dos pacientes. A subjugação da capacidade técnica e científica da equipe de enfermagem, vinculada às questões trabalhistas, políticas, sociais e econômicas, levam os enfermeiros a terem pouco poder decisório nos hospitais, comprometendo, assim, sua autonomia profissional.

No Brasil, o modelo flexneriano assistencial, cartesiano, ainda é dominante, não priorizando a autonomia e a interdisciplinaridade. As organizações de saúde, inseridas no contexto cultural que supervaloriza o papel social do médico, influenciam e sofrem influências sociais que se refletem na estrutura e cultura organizacional das instituições de saúde, alcançando os trabalhadores que nestas desenvolvem suas atividades (Melo et al., 2016; Rocha et al., 2014; Silva \& Kruse, 2012).

Todos esses processos permeiam as questões que foram evidenciadas nos últimos relatos, revelando que, embora tenham uma gama de conhecimentos específicos e eficientes instrumentos de planejamento assistencial, os enfermeiros continuam com suas ações limitadas.

Além da questão da necessidade do trabalho interdisciplinar de fato, não há um suporte psicológico/emocional proporcionado pela instituição, como expresso nos seguintes depoimentos:

[...] seria apoio psicológico para o doente, às vezes até para o profissional que fica muito abalado por falta de preparo, por falta de protocolos [...] Eu acho que a gente poderia treinar os técnicos, dar apoio psicológico e suporte pra que eles entendessem o fim de vida, porque eles também ficam bastante ansiosos... (E 06)

[...] eu acho que a gente deveria ter mais apoio emocional nesse sentido, que não é todo mundo que consegue trabalhar com pessoas assim, e quando a gente se apega, quando o apelo emocional acontece é muito pior. (E 09)

Costa et al. (2017) relatam que a morte é um fator estressor, e enfrentar essa perda de forma isolada, sem estar preparado, pode gerar grande sofrimento mesmo em profissionais experientes. Afirmam que existem lacunas no ensino na área de saúde, envolvendo a morte e o morrer, e que, embora os profissionais busquem educação continuada, não encontram espaços dialógicos nos quais possam compartilhar suas perdas, aflições e sofrimentos, tampouco são amparados, de maneira estruturada, em suas questões emocionais e sociais perante a morte.

Parece uma tendência bastante prevalente a constatação de que, para uma melhor assistência aos pacientes na terminalidade, são necessárias mudanças na rotina e nos protocolos institucionais. Entretanto, tais relatos se sobrepõem aos que sugerem que essas modificações seriam mais profícuas em uma unidade específica, onde esses pacientes seriam mais bem acolhidos e cuidados.

Seguem os depoimentos que falam sobre a importância da criação de protocolos institucionais adequados:

\section{[...] às vezes até para o profissional que fica muito abalado por falta de preparo, por falta de protocolos... (E 06)}

[...] tem até outros [hospitais] que têm protocolo específico pra cuidados paliativos, aqui a gente não tem, ter um protocolo de cuidados paliativos multidisciplinar seria interessante pra todo mundo falar a mesma língua, talvez o que falte é isso... (E 10)

Assim, eи acho que é aquilo que eu falei, tem que ter uma prescrição realmente voltada para cuidados paliativos e padronizar [...] tendo uma equipe que seja padronizada, com esses protocolos, independentemente de estar no CTI ou na enfermaria, eu acho que não interfere, a questão é que falta realmente ter um cuidado voltado... (E 13)

Segundo o manual da ANCP (2012), os cuidados paliativos não devem ser ancorados em protocolos, mas em princípios; são baseados em conhecimentos que pertencem às várias especialidades, de modo a possibilitar intervenções de 
acordo com diversas áreas de conhecimento.

Apesar da falta de direcionamento por protocolos, a palavra foi muito utilizada pela maioria das entrevistadas. Esse dado revela a demanda por uma orientação institucional, mostrando a necessidade de educação e treinamento dos profissionais com o tema emergente.

Os cuidados paliativos requerem conhecimento técnico apurado, além do reconhecimento do ser humano como agente autônomo, em uma assistência pautada por princípios. Desse modo, o foco central é a avaliação do doente para uma paliação de sintomas satisfatória (D’Alessandro et al., 2020).

Os depoimentos a seguir revelam como a alteração nas rotinas propiciaria melhoras significativas no atendimento à clientela em análise:

Isso, eu acho que deveria ser assim. [...] Além de ter a família, ter uma enfermagem treinada, a questão da alimentação, de repente uma questão recreativa, mas na verdade uma coisa que eu percebo que ele sente muito a falta de um ente querido da família e o profissional tem que dar essa liberdade... (E 02)

[...] eu acho que é uma questão, às vezes, a se pensar por que a gente tem essa norma aqui no hospital, que o paciente tenha apenas um acompanhante, mas existem algumas exceções que a gente deve avaliar e que a gente tem que abrir algumas exceções, acho que esse momento é um deles. (E 05)

Ter o direito do acompanhante. Ter o direito não só de uma acompanhante, mas de dois, de ter o direito da visita do acompanhante dele, a visita livre, estar perto de seus familiares, deles poderem chegar perto... (E 12$)$

Assim, o manual da ANCP (2012) elucida que uma das grandes vantagens do cuidado domiciliar é o fato de permitir ao indivíduo ter as suas necessidades atendidas na medida de suas preferências, sem a necessidade de seguir a rigidez das regras e dos horários do hospital. De fato, o controle severo de visitas, acompanhantes, alimentação, regulamentação de higiene, sono e espaço causa uma impessoalidade que vai contra os princípios preconizados.

Rodrigues (2009) cita a rotinização e a ênfase na dimensão técnica do cuidado, que inviabilizam o estabelecimento de vínculos e a identificação das necessidades do paciente para além das necessidades físicas, prevalecendo as práticas e os horários determinados por regras institucionais.

A falta de um norte para as ações também dificulta a identificação do paciente como estando dentro da esfera dos cuidados paliativos, o que atrapalha a comunicação e a continuidade da assistência:

Até que a coisa se torne oficial, a gente fica dependente da decisão médica, acaba sendo um trabalho individual [...] Fica na mão do médico... (E 06)

[...] por isso que eu te falo da questão da equipe preparada, porque aí teria que ter uma prescrição voltada para isso, de enfermagem, e eu não sinto isso na prática, não que a gente não quisesse fazer, as condições em si falam que é paliativo, mas tem aferição de glicemia, de antibiótico venoso, então fica meio confuso, não tem uma padronização. (E13)

Quanto aos resultados encontrados, estudos de Silva et al. (2009) indicam que a falta de comunicação entre a equipe médica, além de pontos de vista diversos, parece constituir fator importante para a ocorrência de distanásia. A decisão de interromper um tratamento considerado fútil nem sempre é um consenso entre profissionais. Por consequência, não é raro que, em plantões diferentes, médicos retomem tratamentos suspensos anteriormente, ou o contrário, motivados por convicções pessoais, criando situações de difícil solução que causam sofrimento para paciente, familiares e equipe.

Quase unanimemente, as enfermeiras referiram as dificuldades enfrentadas para atender com qualidade e dignidade os pacientes em fim de vida dentro das enfermarias não específicas em um hospital geral. Tais críticas são bem evidenciadas nos discursos seguintes: 
Um ambiente mais propício pra ele, porque assim, em uma enfermaria, ele vai ser tratado como um outro paciente qualquer, ele não vai ter nenhuma estratégia, nenhum plano de ação que trabalhe ele de uma forma diferenciada... (E 02)

\section{[...] não expor tanto ele dentro de uma enfermaria porque acaba ele sentindo isso... (E 03)}

O limitador é que é isso, aqui como não é uma coisa voltada só pra cuidado paliativo acaba que esse cuidado não é tão refinado como o que a pessoa precisa... (E 04)

O fato de estar na enfermaria, acho que não ajuda muito [...] acho a gente até consegue, apesar da limitação física, de ter que colocar só os biombos, na enfermaria é um ambiente coletivo, então a gente tem que tentar assegurar alguma privacidade pra esse paciente, tem que ter o cuidado de colocar os biombos... (E 07)

[...] e eu acho que também a própria dinâmica do setor não favorece muito isso, porque se dentro da enfermaria tem esse paciente que está em cuidado paliativo, todo mundo está vendo, compartilha o sofrimento, porque os familiares ficam juntos quando tem acompanhante, esse paciente morre, todo mundo já começa a tomar pra si que aquele momento vai acontecer pra ele também, então isso dificulta como um todo o cuidado para todos, porque eles assumem que pra eles que a qualquer momento vai ser o momento deles... (E 09)

[...] еи acho que faz, eu acho que fica aquela coisa de curiosidade dos outros, se faleceu ou não faleceu, tem pessoas que não gostam de ver a outra partindo... (E 11)

A falta desse espaço próprio parece ser um grande incômodo para o paciente e o profissional, pois a internação em enfermarias comuns não possibilita uma assistência mais qualificada e individualizada, com privacidade e significação desse momento. O enfermo, portanto, fica sujeito a tratamento igual, mesmo estando em uma circunstância diferenciada, em decorrência dessa ambiência.

O termo ambiência se sustenta em três eixos - o espaço que deve garantir conforto aos trabalhadores e usuários, o local que permite a produção de subjetividades no encontro dos atores envolvidos e o espaço usado como ferramenta facilitadora do processo de trabalho, favorecendo a otimização de recursos, o atendimento humanizado, acolhedor e resolutivo (Ministério da Saúde, 2010).

Sendo assim, a organização dos serviços de saúde deve prezar por condições que oportunizem uma atenção humana e acolhedora, bem como favoreçam o desenvolvimento de ações de saúde terapêuticas e resolutivas (Pedrosa et al., 2011).

$\mathrm{O}$ somatório dos fatores ligados à equipe, às limitações vivenciadas pelos pacientes e aos problemas estruturais parecem levar a situações-limite, em que se percebem casos de distanásia/obstinação terapêutica e paradoxos sobre aquilo que é preconizado e o que de fato é realizado.

Eu acho assim, que às vezes, até a gente, os profissionais mesmo, a gente não se coloca ali pra ajudar, pra dar lá o remédio, vira as costas e vai embora, "ah, vai morrer mesmo”, e não é assim, entendeu? Eu acho que eles precisam de mais, por mais que você não possa fazer muita coisa, mas acho que o pouco que você fizer já vai ser muito pra eles... (E 01)

[...] tem pessoas que estão na enfermagem pra um franco aprendizado, porque as pessoas estão ali, tão vendo o outro sofrer, mas as pessoas não amolecem o coração, não esmorecem, continuam fazendo as mesmas coisas, como é que é, repetindo os mesmos erros, eu acho que essa é a palavra e tem pessoas que estão na enfermagem que mostram uma outra forma do cuidado, uma outra forma do olhar, é uma outra maneira de olhar, que é um ser humano, porque às vezes se lida ali como se não fosse uma pessoa ali, "ah, já tá sedada, daqui a pouco tá morrendo". (E 02)

[...] tem alguns momentos que as pessoas não aceitam que não tem mais tratamento de fato, não só a família e o paciente, mas o profissional. A gente se sente um pouco impotente, de não ter mais a oferecer... (E 07)

Segundo Elshaug et al., 2017, citado por D’Alessandro et al. (2020), o cuidado adequado é definido como o cuidado individualizado que otimiza a saúde e o bem-estar ao proporcionar o que é necessário, desejado e clinicamente efetivo, de 
maneira acessível, equitativa e responsável quanto à alocação de recursos.

As preferências e os valores dos pacientes precisam ser levados em consideração, sobretudo nessa área cinzenta, tornando-se fundamentais para apoiar a definição do que faz ou não sentido para o tratamento (D’Alessandro et al., 2020).

De acordo com Borges e Mendes (2012), o modelo centrado na cura, aliado ao tabu da morte, favorece tanto a adoção da obstinação terapêutica quanto o abandono do doente; nas duas situações a morte social antecede a morte biológica, o que acaba por trazer mais sofrimento a pacientes, familiares e profissionais.

Diante desse cenário, o paciente na terminalidade, então, é “descartado", uma vez que, sob a ótica curativa de um hospital terciário, já não restariam recursos terapêuticos.

Isso mesmo, às vezes o paliativo é um pouco descartado, ele já está morrendo mesmo... (E 03)

[...] é como se não importasse aquela pessoa, cuidado paliativo, então deixa pra lá, e não é assim... (E 04)

[...] porque eu sinto isso, porque as pessoas falam: "ah, é paliativo morreu”, "ah, mas a gente já sabia que ia morrer”. Gente, não é assim, gente... (E 14)

Azevedo (2020) relata que sempre que um paciente está prestes a morrer, uma certa angústia aflora, podendo conduzir o paciente ao abandono. Cita a autora Herzlich, no seu ensaio sobre a morte, destacando que, por não saberem lidar com as emoções despertadas pela ambiguidade e pela incerteza da terminalidade, os profissionais tendem a se distanciar dos moribundos, após se recusarem a admitir a proximidade do óbito, e tratam a pessoa doente como se já estivesse morta. É um fenômeno de dupla negação, tanto da morte quanto da vida que resta.

Existe também a necessidade de uma reflexão mais aprofundada acerca do paciente em cuidados paliativos na terminalidade da vida, "descartado" na enfermaria, trazendo a discussão da biopolítica e tanatopolítica na tentativa de entendimento de certos modelos de regulamentação do corpo hospitalizado em cuidados paliativos.

Seguindo-se esse padrão, o paciente em cuidados paliativos, apesar de apresentar um risco de óbito muito próximo, vê-se atendido por uma equipe que não consegue prestar uma assistência holística e satisfatória direcionada às suas necessidades. Não sendo possível a cura, os esforços e recursos parecem perder o sentido, sendo o paciente destituído de sua história de vida, esperando o momento do óbito. Esse indivíduo passa, então, a ser considerado "indesejado" e "invisível”, causando certo desconforto na equipe.

O paciente moribundo, não viável, sem perspectivas terapêuticas, nesse ponto se assemelharia a uma vida nua, desqualificada no sentido valorável da sociedade capitalista; e também ao homo sacer, no sentido de ser uma vida sacra (inviolável, inscrita na proteção aos direitos humanos), mas ao mesmo tempo matável, entendendo-se que, embora existam tentativas de justificar a ortotanásia para o cuidado paliativo, na realidade, não existiria o momento "certo" para a constatação do óbito, havendo sempre o momento em que a equipe decide não mais investir, diante do aparato tecnológico atual (eutanásia passiva).

Apresentando essa perspectiva, Agamben (2007) destaca a figura do homo sacer como aquele indivíduo condenado na antiga sociedade romana, que havia cometido um delito e que, por isso, não poderia ser sacrificado aos deuses; porém, se alguém o matasse, não lhe seria imputada uma pena; essa vida não seria sacrificável, entretanto, seria matável. Sendo assim, a vida nua na atualidade se confundiria com a vida sacra do homo sacer, essa vida que não se sacrifica, porém se mata.

Portanto, paira essa reflexão sobre as formas de vida inseridas no contexto hospitalar - poderiam ser consideradas "sobrevidas", tanto na UTI quanto nas unidades abertas ou enfermarias, quando os profissionais de saúde as destituem de nome e biografia, quando as categorizam como "não viáveis" e fora de possibilidades terapêuticas e, muitas vezes, as classificam e/ou carimbam, como na terminalidade, aguardando o momento da morte. 
Entendendo de forma geral como os temas da vida e da morte são contabilizados no âmbito político, e como atualmente ocorrem esses processos de controle e regulamentação, emerge a dimensão da tanatopolítica.

Sob o olhar da biopolítica moderna, a tanatopolítica se apresenta na convergência entre a decisão soberana sobre a vida matável e o papel de cuidar do corpo biológico da nação, e delimita o ponto em que a biopolítica se transforma em tanatopolítica. "Na biopolítica moderna, soberano é aquele que decide sobre o valor ou sobre o desvalor da vida enquanto tal" (Agamben, 2007, p. 149).

De acordo com essas reflexões e trazendo a contribuição de Menezes (2004), o discurso moral dos paliativistas trata de uma nova forma de regulação social e emocional sobre o fim da vida. "A construção de uma imagem serena e aceita da morte, conjugada à expressão adequada de sentimentos dos que assistem ao moribundo, reforça o imperativo de um controle de si civilizado" (p. 210). Os cuidados paliativos seriam um novo dispositivo social de domínio das emoções perante a morte.

Em uma correspondência contemporânea, Menezes (2004) lembra que o modelo paliativo se originou como contraponto ao poder médico e suas instituições, porém esse "novo" modelo de humanização do morrer se dá às custas da dependência de uma rede ampliada de profissionais, não consistindo em "uma libertação do aparato médico, mas sim de um refinamento e capilarização das suas formas de exercício de controle” (p. 214).

Isto posto, faz-se necessário conhecer a exata dimensão da responsabilidade de voltar-se para o ser humano com todas as suas particularidades, no intuito de que ele possa sempre estar no centro do cuidado com toda a sua individualidade, valorizando, assim, a biografia de cada sujeito, trazendo qualidade de vida e, consequentemente, de morte. Do contrário, as equipes de saúde poderiam descartar os pacientes, inconscientemente, de forma política.

No que tange ao local da morte, é colocado como dificultador o ambiente hospitalar, acreditando algumas entrevistadas que é melhor que a morte ocorra no ambiente domiciliar, citando, inclusive, o processo de desospitalização:

Sim, o que eu gostaria mesmo de fazer seria fazer esse paciente ir para casa, para tentar morrer em casa, cenário ideal pra mim, no mundo de Alice... (E 10)

Eu acho que primeiro que ele tem que ter realmente o seu parente perto, até porque eu acho que o paciente paliativo, que está paliativo, ele tinha que estar em casa, ele não deveria estar realmente internado... (E 12)

[...] talvez uma alta mais precoce paraa ele ter, em casa, de repente um óbito em casa de maneira mais digna, perto do familiar no ambiente dele. É uma lacuna muito grande... (E 13)

Segundo D'Alessandro et al. (2020), estudos revelam que grande parte dos indivíduos optaria por falecer em casa. Entretanto, metade morre em nosocômios, mostrando que há espaço para o desenvolvimento dessa atenção, podendo beneficiar os doentes e o sistema de saúde, a fim de otimizar recursos para oferecer uma assistência alinhada com os desejos de cuidados preferenciais.

Azevedo (2020), em seu trabalho "O melhor lugar para morrer", comenta que o discurso contemporâneo da "boa morte", ao exaltar uma revisita ao passado e sua morte domiciliar, pode parecer sedutor, porém lembra que o paciente, a família e a equipe precisam afinar expectativas e práticas. Para ser protagonista de sua biografia, o doente deve estar no comando da situação, sob o risco de a falta de suporte social transformar a "boa morte" no domicílio em uma experiência negativa, com repercussões sérias também para os familiares.

A morte em domicílio envolve uma série de fatores que precisam estar disponíveis: pessoas com disponibilidade física, de tempo e emocional; espaço condizente, incluindo uma habitação minimamente acessível e com recursos sanitários; disponibilidade financeira para arcar com todos os insumos necessários e com a eventual contratação de cuidadores. Somandose a todos esses fatores, há ainda o indispensável controle rigoroso de sintomas (que pode não ser possível em casa) e os medos já discutidos anteriormente, bem como o receio de não conseguir o atestado de óbito. 
Para algumas entrevistadas, não parece ter tanta relevância o local da morte, pois o foco está na assistência voltada para o paciente na terminalidade.

[...] pra mim o cuidado paliativo, ele pode ser feito tanto no hospital quanto em casa, vai depender da clínica do paciente, depende da medicação que ele tiver que usar, vai acabar tendo que ficar internado mesmo... (E 10)

[...] ele não deveria realmente ficar internado, mas já que ele está internado, deve ter mais um aconchego... (E 12)

Em vista disso, Azevedo (2020) descreve que o melhor lugar para morrer deve ser escolhido com antecedência, avaliando-se todas as variantes de cada cenário. Deve ser um local em que existam recursos suficientes para lidar com as demandas da pessoa doente, um lugar onde sua biografia possa ser respeitada até o fim, onde não falte acesso imediato às medicações necessárias para o conforto nos momentos finais. Conclui que o melhor lugar precisa ser aquele que promova a experiência do cuidado, que envolva o paciente e todos que o cercam.

Embora atualmente haja um resgate da morte domiciliar, as melhores evidências mostram que não existe um único local para se realizar a assistência paliativa. O melhor lugar é onde o doente que deseja e precisa desse cuidado estiver, em casa, no hospital, ambulatório, instituição de permanência longa ou hospice, de acordo com a Worldwide Palliative Care Alliance.

Em determinado ponto, a análise pairou sobre um fenômeno emergente, a pandemia da covid-19, que surtiu impacto na enfermagem, visto que as consequências na assistência foram verbalizadas nas entrevistas.

Ter a família, visita de amigos, agora não está podendo por causa da pandemia, eu até concordo porque é muito arriscado, mas eu acho muito importante... (E 01)

[...] alguns pacientes em cuidados paliativos, ainda mais nesse momento em que a gente tá lidando atualmente em questão de pandemia, não é o ideal que mais de um familiar esteja presente, mas em outras situações, em outros momentos já aconteceu, aí foi uma questão de bom senso até a gente abriu um pouquinho de exceção. (E 05)

[...] deixar vários acompanhantes, a família inteira, na realidade não podemos, não tem como botar mais de um acompanhante, não tem como por causa da pandemia, óbvio, mas assim isso seria uma situação hipotética, então só tem um acompanhante, seria mais legal poder ter outros... (E 10)

Ter o direito da visita do acompanhante dele, a visita livre, estar perto de seus familiares, deles poderem chegar perto. Eu sei que no momento não dá pela covid, mas, teria que ter esse direito... (E 12)

[...] porque a gente está vivendo o momento [pandemia] que na hora do óbito tem essa questão toda, até mesmo antes, que o doente paliativo, essas famílias não são acolhidas mais... (E 14)

A questão das visitas proibidas ou limitadas, assim como a questão do luto, foram preocupações das entrevistadas, que precisaram lidar com essa nova realidade.

A pandemia por covid-19 trouxe mudanças significativas e inúmeras perdas para o cotidiano hospitalar. Muitas características comuns ao luto estão sendo experimentadas no contexto atual de pandemia, além das mudanças abruptas na rotina, no convívio social e profissional. (Fundação Oswaldo Cruz, 2020).

É preciso reconhecer a experiência de enlutamento e construir novos rituais de despedida a fim de lidar com o luto. Os rituais, como as visitas hospitalares para despedida, velório, caixão aberto, translado do corpo para outra localidade, enterro, culto religioso, estão alterados ou não podem ocorrer devido à proibição de aglomerações e à recomendação de distanciamento social, o que, por vezes, aumenta a sensação de irrealidade da morte. Nesse cenário, salienta-se a importância da adaptação para realização de algum ritual de despedida, pois através dele é possível construir significados para a perda, organizar-se diante de algo tão desestruturante como a morte pela covid-19, e dar algum fechamento à experiência vivida (D’Alessandro et al., 2020). 


\section{Propostas das enfermeiras para melhoria da assistência em cuidados paliativos na terminalidade}

Esta subcategoria se constituiu a partir de um espaço oferecido às participantes para falarem sobre o que gostariam que fosse diferente no seu cotidiano laboral no sentido de melhorar a assistência ao paciente em cuidados paliativos na terminalidade da vida.

Ao dar voz às enfermeiras, grande parte das entrevistadas citou a importância da capacitação e do treinamento em serviço para otimizar os cuidados prestados.

Bom, no primeiro momento eu acho que tinha que preparar a equipe dos profissionais... (E 02)

[...] acho que tem que capacitar todo mundo... (E 03)

Então, eu acredito que mais cursos, porque eu acho que quando você capacita uma pessoa, mediante a capacitação, a pessoa consegue trabalhar de forma melhor. (E 08)

Segundo Cezar et al. (2019), um dos fatores colocados como empecilho para a prática da assistência paliativa é a formação do profissional. Nesse sentido, a tomada de consciência de órgãos gestores da saúde pública quanto à necessidade dos cuidados paliativos é considerada um passo essencial. Pesquisas sinalizam que há diferença na assistência prestada pelo profissional com formação em cuidados paliativos e aqueles que não a possuem. Os profissionais sem esse preparo apresentam conhecimento insatisfatório comparado aos que têm formação prévia, além disso, aplicam o conhecimento na prática.

Cezar et al. (2019) indicam também a necessidade de uma ampla disseminação de conhecimento e educação sobre cuidados paliativos entre os profissionais da saúde. Para os autores, o início deve ocorrer no processo de formação, estendendo-se durante a prática, tanto pela procura pessoal por conhecimento como por ações de educação permanente.

Também foram reveladas falas que abordam a importância de um suporte psicológico/emocional a ser oferecido para a equipe, além do apoio teórico:

[...] você tem que ter uma estrutura também, tem que trabalhar o psicológico desse profissional pra ele não adoecer, pra ele não entrar em depressão, porque temos que lidar com alegria, com satisfação, tentar mostrar pra ele o lado rosa da vida, vamos dizer assim, o lado azul da vida, porque ele sabe que ele está partindo quando ele está lúcido, a família também. (E 02)

A segunda coisa é oferecer um pouco de suporte emocional pros profissionais de enfermagem... (E 09)

Segundo D'Alessandro et al. (2020), a melhor forma de aprimorar o cuidado é por meio da atualização técnica e do autocuidado. É preciso integrar à rotina das equipes de saúde atividades que proporcionem prazer e bem-estar aos profissionais e que os conectem com as pessoas e com o que é importante para cada um.

Almeida et al. (2014) orientam que os dirigentes de instituições de saúde devem (re)pensar as rotinas e fornecer subsídios em forma de cursos, oficinas e discussões para que os profissionais desenvolvam bem suas atividades, visando ao bem-estar do paciente e sua família. Desse modo, os enfermeiros também precisam ser assistidos de forma holística e reconhecidos como seres humanos biopsicossociais e espirituais e não meramente como seres provedores de cuidados.

Acerca do trabalho em equipe aludido pelas enfermeiras, citou-se a relevância de investimento em trabalho interdisciplinar:

Eu acho que de maneira geral o que poderia ser melhor é uma participação mais multidisciplinar da avaliação desses casos [...] eu quero dizer, o envolvimento da família, o contato, o psicológico, você ter um psicólogo, ter uma assistente social, ter uma equipe junto discutindo o caso... (E 07) 
Primeira coisa fortalecimento de vínculo multiprofissional, isso é pra mim o ideal em qualquer lugar, e que acho que aqui funciona até certo ponto... (E 09)

Assim, a assistência em cuidados paliativos pode e deve ser desenvolvida pela equipe multiprofissional, demonstrando que essa necessidade perpassa pela complexidade na assistência (Espíndola et al., 2018).

Contudo, é notado que existe uma estruturação hospitalar centralizada na figura do médico. Desse modo, considerando que o cuidado paliativo preconiza um trabalho em equipe sem a verticalização prevalente nas unidades de saúde, tem-se um distanciamento profundo entre a assistência desejada e a que realmente é prestada, conforme mencionado no seguinte depoimento, em que a entrevistada é da opinião de que a conduta deveria acontecer em equipe:

A questão do fortalecimento da equipe multiprofissional no atendimento dos casos, porque aqui quem paliativa é o médico. Eu acho que o cuidado paliativo, ele deve ser, ele deve acontecer, a definição de paliativar um paciente deve ser tomada em conjunto... (E 09)

A centralidade no cuidado engloba reconhecimento e respostas às necessidades do paciente e dos familiares pela equipe transdisciplinar. Embora haja um reconhecimento das conquistas tecnológicas, é necessária uma transição entre tentativas legítimas de manutenção da vida e a abordagem paliativa, sem desconsiderar a dimensão da finitude humana (Bertachini \& Pessini, 2011).

Quanto aos determinantes que dizem respeito ao paciente e à família, a autonomia foi referenciada como um fator imprescindível para que possa haver um processo de morrer com dignidade:

[...] eu acho isso uma morte digna, uma morte que ele pode falar o que ele quer ali naquele momento, por isso que eu acho que tem que ser conversado antes dele chegar ao rebaixamento de nível de consciência. (E 11)

O paliativismo tem como preceito o respeito às escolhas do paciente e à sua autonomia. Entretanto, para que o paciente tenha condições de escolha, é necessário o esclarecimento das opções e consequências dos tratamentos disponíveis. Nesse momento, a oposição entre equipe, pacientes e familiares pode levar a conflitos e negociações. Assim, a primazia do princípio da autonomia conduz a equipe a estabelecer uma nova relação com o paciente, na qual a tomada de decisão necessita ser compartilhada (Menezes, 2004).

Apesar de ser difícil a implementação de muitos dos pressupostos dos cuidados paliativos, torna-se urgente a disseminação da cultura, dentro do hospital, relacionada a essa tomada de decisão compartilhada.

A alteração de rotinas vem ancorada também nesse respeito à autonomia, pois, no intuito de prestar uma assistência de excelência amparada nas melhores evidências, é preciso uma readequação para melhor cuidar dos pacientes em cuidados paliativos.

Essa é uma norma aqui no hospital, que o paciente tenha apenas um acompanhante, mas existem algumas exceções que a gente deve avaliar e que a gente tem que abrir algumas exceções... (E 05)

Pacientes que têm condição ainda de verbalizar o que querem, o desejo que têm, tem que ser viabilizado... (E 07)

Menezes (2004) refere que o ideário da "boa morte" presume que o paciente possua o máximo de controle no processo de morte, o que depende da atuação da equipe profissional, porém essa mesma equipe constrói uma hierarquia de prioridades que nem sempre coincidem com as escolhas do próprio doente. A "boa morte" implicaria perecer ao próprio jeito do doente, o que forçosamente resultaria na perda do controle das circunstâncias do morrer por parte da equipe.

Sendo assim, torna-se fundamental uma especificação de rotinas para essa clientela, o que seria possível com um 
serviço de cuidados paliativos, no qual essa adequação e flexibilização das normas hospitalares teriam condições de ser implementadas. Essa constatação leva à proposta seguinte apresentada pelas profissionais - a existência de um espaço específico para atendimento dos pacientes em cuidados paliativos, que foi citada quase de forma unânime pelas enfermeiras entrevistadas:

Eu acho que deveria ter um setor específico pra esse tipo de paciente [...] não é que seria um setor, por exemplo, cuidados paliativos, fim da vida não, mas um setor que tivesse profissionais com essa sensibilidade, porque tem muita gente que não tem essa percepção [...] um setor perfeito seria o que tem quartos, mais aconchegante. Tem a possibilidade de estar com um familiar. (E 02)

Eu só colocaria o espaço, se a gente tivesse um espaço adequado de separar dos outros enfermos seria ideal [...] Eu acho que ficaria mais tranquila, não ficaria pensando que ali ela tá sentindo, o paciente está sentindo dor e ao mesmo tempo está vendo o outro ali rindo, vendo televisão, ter um espaço reservado, que poderia ter vários paliativos, juntar eles mesmo, é um sofrimento só, a gente sabe que tá no final da vida, tá sentindo aquela dor que não tem como voltar, melhor do que ficar com outro rindo, ali o outro se beijando, sabe? Porque não tem separação. Não é excluir ele, mas acho que limitar ele, o espaço dele, pra ele ter uma morte serena. (E 03)

[...] a gente poderia ter um ambiente mais individualizado, digamos assim, se fosse possível, deixar o paciente em um quarto mais isolado, em que ele possa ter um momento a sós com a família. (E 07)

De acordo com a ANCP (2012), o cuidado paliativo em ambiente hospitalar pode ser feito de três maneiras, em Unidade de Cuidados Paliativos, por Equipe Consultora ou Volante, ou por Equipe Itinerante que é acionada conforme a percepção do médico assistente. No hospital estudado, atualmente, trabalham duas Equipes Consultoras ou Volantes. Uma equipe é ligada à Clínica da Dor e acompanha os casos oncológicos e a outra atende os casos não oncológicos. Essas equipes respondem a pareceres sempre requisitados pela equipe médica. Ressalta-se que tais equipes não têm o suporte de todas as especialidades de equipe interdisciplinar preconizadas.

Conforme revelado nos depoimentos, prestar assistência em um hospital geral, em unidades abertas ou enfermarias, a uma clientela que exige um olhar tão peculiar, é um desafio diário. O fato de estarem com outros pacientes de especialidades e demandas diversas causa uma dificuldade em personalizar o cuidado ao paciente na terminalidade.

Importante citar pesquisa realizada em Londrina, Paraná, em 2003, que avaliou pacientes fora de possibilidades terapêuticas internados em um hospital universitário (Roncarati et al., 2003). Verificou-se que a equipe de saúde tem grande dificuldade em reconhecer um doente candidato a receber cuidados paliativos. O estudo sugeriu a criação de uma unidade específica para cuidados paliativos nas instituições, além de ambulatório especializado. Ademais, indicou como necessária uma equipe de saúde específica e itinerante, que esteja capacitada para atuar nas diversas áreas, inclusive nos domicílios, fornecendo informações e apoio, sobretudo em questões como o alívio da dor e o luto.

Finalmente, o que importa é que esses doentes e suas famílias precisam ser mais bem atendidos e terem suas necessidades satisfeitas. Essas medidas propiciariam a autonomia do paciente para a tomada de decisões referentes a seu tratamento e o ajudariam a viver e a enfrentar o morrer da melhor forma possível (Roncarati et al., 2003).

\section{Conclusão}

Neste estudo, discutiu-se a rotina das enfermeiras diante do desafio dos cuidados paliativos na terminalidade em enfermarias de um hospital universitário.

Como facilitadores, foram citadas as características da própria enfermagem e o centro do seu trabalho, que é o cuidado. As enfermeiras já têm arraigado o processo do "cuidar"; sendo assim, o cuidado paliativo só precisaria de ajustes, muitos deles institucionais, para que ocorresse com excelência. Palavras como conforto, empatia, amor, carinho, acolhimento, aconchego e humanização foram utilizadas como sendo parte da prática das enfermeiras em seu cotidiano, bem como a 
religiosidade, que parece abrandar o contato frequente com a morte. O fato de estarem em um hospital universitário de referência nacional também foi sinalizado como favorável para uma assistência qualificada.

Quanto aos fatores limitadores, as profissionais entendem ser difícil o enfrentamento da morte, tanto do outro quanto a projeção da morte de si mesmo. Contudo, o medo e a solidão frequentemente experimentados não são discutidos, tendo a maioria das enfermeiras que reprimir ou encontrar formas individuais de resolução dessas angústias. As limitações enfrentadas pela equipe de enfermagem em relação ao paciente costumam estar ligadas também à negação da morte, à ausência da família e acompanhantes ou à não aceitação por parte destes do processo de finitude.

O maior número de dificuldades apontadas referiu-se aos entraves institucionais. A falta de educação continuada dentro do hospital, associada à ausência de condutas sobre cuidados paliativos, são fatores que fazem com que os pacientes não sejam colocados dentro da esfera dos cuidados paliativos, ainda que sejam assim considerados pelas enfermeiras, recebendo um cuidado aquém das necessidades apresentadas ou sendo submetidos à obstinação terapêutica.

A falta de funcionários, em termos de diferentes profissões que deveriam compor a equipe, assim como o quantitativo reduzido, são outros fatores que parecem prejudicar a assistência integral ao paciente. Emergiram falas que destacam a ausência do trabalho interdisciplinar, tendo na figura do médico o detentor do saber e único definidor das condutas a serem tomadas, o que gera falta de valorização das outras categorias e tratamento inadequado ao doente em algumas circunstâncias. Soma-se a isso o fato de a pesquisa ter ocorrido em um hospital universitário, em um modelo centrado na cura, o que favorece a invisibilização do paciente paliativo.

O fato de o processo de morte se dar no interior do hospital também incomoda uma parte das entrevistadas, para a qual esse ambiente carece de acolhimento e humanização. Algumas verbalizaram que a morte digna deveria acontecer no domicílio, outras não viram diferença sobre o local, desde que o protagonista fosse o paciente.

Durante a análise desta questão, surgiu novamente a problemática dos modelos importados para incorporação no Brasil. Nesse caso, a integração da morte contemporânea domiciliar necessitaria de ajustes para adaptação ao nosso país.

A rigidez hospitalar das normas e rotinas institucionais configurou um empecilho para o paciente na finitude, na visão das enfermeiras; o fato de estar hospitalizado o condiciona a um tratamento igual ao de qualquer outro paciente, tirando desses indivíduos a possibilidade de desfrutarem de algum prazer nos momentos de fim de vida.

Tal constatação reflete o mais predominante obstáculo para uma assistência centrada nesse paciente - a internação em enfermarias comuns. As profissionais entrevistadas alegam que não há como respeitar a biografia e o protagonismo desse paciente quando ele está hospitalizado com vários outros, clínicos ou cirúrgicos, que vivenciam realidades diversas. As queixas assinalam um ambiente físico inapropriado, que não fornece privacidade e não incentiva o exercício da autonomia. Os problemas também indicam que o acompanhamento por equipes de rotinas e plantões diferentes dificultam uma padronização na assistência.

A pandemia por covid-19, que assolou o mundo, foi mencionada em vários depoimentos, por ter prejudicado principalmente as visitas e a presença do acompanhante. Sendo assim, um quadro que já poderia ser maléfico, em razão de o paciente estar hospitalizado, acabou por deixá-lo mais isolado neste momento de fragilidade, trazendo muito sofrimento para o processo de morte, tanto para o doente quanto para sua família.

Com relação às propostas, grande parte convergiu para o âmbito institucional. O oferecimento de capacitação para a equipe e espaços para acompanhamento emocional ou psicológico parecem ser demandas que, se atendidas, permitiriam que a equipe se sentisse apta e segura para proporcionar um cuidado de qualidade a esses pacientes, pois conseguiriam lidar com suas próprias limitações relacionadas à morte e ao desconhecimento técnico-científico.

A ampliação do quantitativo de funcionários, tanto de enfermagem como de outras categorias, foi destacada como fator para melhoria da assistência. A promoção do trabalho interdisciplinar e a horizontalização das condutas também parecem 
ser motivo para tornar o trabalho mais gratificante para os profissionais e mais qualificado para os pacientes.

Outra sugestão foi a alteração de normas e rotinas para essa clientela em especial, já que necessitam aproveitar com plenitude e qualidade a vida que ainda é presente, o que introduz a proposta que foi uma das mais citadas, a criação de um espaço para a assistência ao paciente paliativo, que poderia ser traduzido como um setor com essa finalidade.

Como limitações da pesquisa, ressalta-se a questão da justiça, que merece ser mais bem abordada em pesquisas futuras, com um olhar mais voltado para o estudo dos problemas brasileiros e não importados. Acredita-se que o problema do Brasil não seja tanto a distanásia, tão prevalente nos estudos elaborados no país, mas a dificuldade de acesso ao Sistema Único de Saúde, causando uma mistanásia, aquela que não oferece à população a oportunidade sequer de diagnóstico, quiçá de tratamento, uma "morte e vida severina", uma "morte infeliz".

Além dessa importação de modelos em pesquisa, é importante considerar a própria implantação dos cuidados paliativos no Brasil, pois, se introduzida predominantemente por médicos, isso por si só geraria um paradoxo, uma vez que o modelo vem a mexer com a hegemonia dessa profissão, democratizando as informações e decisões.

Outra abordagem que merece ser aprofundada paira sobre esses corpos invisibilizados nos leitos das enfermarias; são invisíveis porque, primeiramente, são incômodos, indesejados; ocupam um leito em um hospital curativo, com uma equipe de jovens médicos formados para "salvar" vidas. A tese defendida é de que são, em parte, "vida nua" (enquanto vida desqualificada na sociedade capitalista) e homo sacer, no sentido de uma vida sacra (inviolável, inscrita na proteção aos direitos humanos), mas, ao mesmo tempo, matável, pois, na realidade, não existe o momento "certo" para a constatação do óbito, havendo sempre o instante em que a equipe decide não mais investir, diante do aparato tecnológico atual. Os pacientes, em alguns casos, então recebem um "selo" de cuidados paliativos, o que pode lhes render uma antecipação da morte, uma morte social dentro da instituição.

Os estudos importados embaçam a visão da ciência local quando se pensa que o problema predominante da morte ruim no Brasil é a morte com o indivíduo intubado dentro de um CTI. Este pode ser um problema central de outro país, mas não seria o caso brasileiro. Esse indivíduo que recebeu o tubo passou por inúmeras portas estreitas e está sendo cuidado, com uma assistência passível de reflexão. Não que exista impertinência nessas reflexões, porém não se podem negar as evidências de um número estrondoso de usuários que clamam por uma atenção básica digna.

Sendo assim, sugere-se a realização de mais estudos referentes à percepção de profissionais e usuários sobre os cuidados em saúde sob a perspectiva bioética, sobretudo com enfoque na justiça e na biopolítica, bem como a investigação das temáticas abordadas atravessadas pelos problemas brasileiros.

\section{Referências}

Academia Nacional de Cuidados Paliativos (Brasil). (2012). Manual de Cuidados Paliativos da Academia Nacional de Cuidados Paliativos (ANCP) (2a ed.). Sulina.

Agamben, G. (2007). Homo Sacer: O poder soberano e a vida nua I. Editora UFMG. 207 p.

Almeida, C. M. L., Sales, C. A., \& Marcon, S. S. (2014). O existir da enfermagem cuidando na terminalidade da vida: Um estudo fenomenológico. Rev. esc. enferm. USP, 48(1), 34-40. https://doi.org/10.1590/S0080-623420140000100004

Araújo, K. M., \& Leta, J. (2014). Os hospitais universitários federais e suas missões institucionais no passado e no presente. Hist Cienc Saude Manguinhos, 21(4), 1261-1281. https://doi.org/10.1590/S0104-59702014005000022

Ares, L. P. M. (2015). O uso das tecnologias não invasivas de cuidado de enfermagem obstétrica em uma maternidade de alto risco. [Trabalho de conclusão de Curso de Especialização em Enfermagem Obstétrica, Universidade do Estado do Rio de Janeiro].

Ariès, P. (2017). História da morte no Ocidente. Nova Fronteira. 288 p.

Azevedo, D. L. (2020). O melhor lugar para morrer. Appris. 160 p.

Baère, T. D., Faustino, A. M., \& Miranda, A. F. (2017). A importância da prática interdisciplinar da equipe de saúde nos cuidados paliativos. Rev. Portal de Divulgação, (53), ano 7, 5-19. https://revistalongeviver.com.br/index.php/revistaportal/article/viewFile/673/742 
Bardin, L. (2011). Análise de conteúdo. Edições 70.

Bautista-Rodriguez, L. M., Arias-Velandia, M. F., \& Carreno-Leiva, Z. O. (2016). Percepción de los familiares de pacientes críticos hospitalizados respecto a la comunicación y apoyo emocional. Rev Cuid, 7(2), 1297-1309. https://doi.org/10.15649/cuidarte.v7i2.330

Beauchamp, T. L., \& Childress, J. F. (2002). Princípios da ética biomédica. Loyola.

Bertachini, L., \& Pessini, L. (2011). Conhecendo o que são cuidados paliativos: conceitos fundamentais. In L. Bertachini, L. \& L. Pessini (Orgs.), Encanto e responsabilidade no cuidado da vida: Lidando com desafios éticos em situações críticas e de final de vida (pp. 19-55). Paulinas; Centro Universitário São Camilo.

Bifulco, V. A., \& Iochida, L. C. (2009). A formação na graduação dos profissionais de saúde e a educação para o cuidado de pacientes fora de recursos terapêuticos de cura. Rev. Bras. Educ. Med., 33(1), 92-100. https://doi.org/10.1590/S0100-55022009000100013

Borges, M. S., \& Mendes, N. (2012). Representações de profissionais de saúde sobre a morte e o processo de morrer. Rev Bras Enferm., 65(2), 324-331. https://doi.org/10.1590/S0034-71672012000200019

Cezar, V. S., Waterkemper R., Rabin, E. G., Castilho, R. K., \& Reys, K. Z. (2019). Educação permanente em cuidados paliativos: Uma proposta de pesquisaação. Rev. pesqui. cuid. fundam. (Online), 11(2), 324-332. https://doi.org/10.9789/2175-5361.2019.v11i2.324-332

Conselho Federal de Enfermagem (Brasil). (2017). Resolução n. 543, de 12 de maio de 2017. Código de Ética dos Profissionais de Enfermagem. Diário Oficial da União.

Costa, D. T., Garcia, L. F., \& Goldim, J. R. (2017). Morrer e morte na perspectiva de residentes multiprofissionais em hospital universitário. Rev. bioét. (Impr.), 25(3), 544-553. https://doi.org/10.1590/1983-80422017253211

Costa, P. C. P., Garcia, A. P. R. F., \& Toledo, V. P. (2016). Acolhimento e cuidado de enfermagem: Um estudo fenomenológico. Texto Contexto Enferm., 25(1), e4550015. https://doi.org/10.1590/0104-07072016004550014

D’Alessandro, M. P. S., Pires, C. T., \& Forte, D. N. (2020). Manual de cuidados paliativos. Hospital Sírio-Libanês; Ministério da Saúde. 175 p. https://antigo.saude.gov.br/images/pdf/2020/September/17/Manual-CuidadosPaliativos-vers--o-final.pdf

Dodou, H. D., Sousa, A. A. S., Barbosa, E. M. G., \& Rodrigues, D. P. (2017). Sala de parto: condições de trabalho e humanização da assistência. Cad. Saúde Colet., 25(3), 332-338, 2017. https://doi.org/10.1590/1414-462X201700030082

Elias, M. A., \& Navarro, V. L. (2006). A relação entre o trabalho, a saúde e as condições de vida: Negatividade e positividade no trabalho das profissionais de enfermagem de um hospital escola. Rev Latino-am Enferm., 14(4), 517-525. https://doi.org/10.1590/S0104-11692006000400008

Espíndola, A. V., Quintana, A. M., Farias, C. P., \& München, M. A. B. (2018). Relações familiares no contexto dos cuidados paliativos. Rev. Bioét., 26(3), 371-377. https://doi.org/10.1590/1983-80422018263256

Felli, V. E. A. (2012). Condições de trabalho de enfermagem e adoecimento: Motivos para a redução da jornada de trabalho para 30 horas. Enferm. foco (Brasília), 3(4), 178-181. https://pesquisa.bvsalud.org/portal/resource/pt/bde-24604

Fundação Oswaldo Cruz. (2020). Saúde mental e atenção psicossocial na pandemia COVID-19: Processo de luto no contexto da COVID-19. https://www.fiocruzbrasilia.fiocruz.br/wp-content/uploads/2020/04/Sa\%C3\%BAde-Mental-e-Aten\%C3\%A7\%C3\%A3o-Psicossocial-na-Pandemia-Covid-19processo-de-luto-no-contexto-da-Covid-19.pdf

Gaspar, R. B. (2017). O gerenciamento do cuidado de enfermagem para defesa da autonomia dos idosos em terminalidade da vida. [Dissertação de Mestrado em Enfermagem, Universidade Federal do Rio de Janeiro].

Heidegger, M. (1997). Ser e Tempo: Parte II (6a ed., vol. 2). Vozes.

Instituto Brasileiro de Geografia e Estatística. (2015). Síntese de indicadores sociais: Uma análise das condições de vida da população brasileira: 2015. https://biblioteca.ibge.gov.br/visualizacao/livros/liv95011.pdf

Kovács, M. J. (2003). Educação para a morte: Desafio na formação de profissionais de saúde e educação. Casa do Psicólogo; FAPESP.

Kruse, M. H. L., Vieira, R. W., Ambrosini, L., Niemeyer, F., \& Silva, F. P. (2007). Cuidados paliativos: Uma experiência. Rev HCPA, 27(2), 49-52. Disponível em: https://lume.ufrgs.br/handle/10183/28898

Kübler-Ross, E. (2008). Sobre a morte e o morrer (9a ed.). WMF Martins Fontes.

Marreiro, C. L. (2014). O direito à morte digna: Uma análise ética e legal da ortotanásia. Appris. 191 p.

Melo, C. M. M., Florentino, T. C., Mascarenhas, N. B., Macedo, K. S., Silva, M. C., \& Mascarenhas, S. N. (2016). Autonomia profissional da enfermeira: Algumas reflexões. Esc. Anna Nery, 20(4), e20160085. https://www.scielo.br/j/ean/a/9hF3zZdzdVD5PsTLYg4pkkF/?format=pdf\&lang=pt

Mendes, A. M. (2007). Novas formas de organização do trabalho, ação dos trabalhadores e patologias sociais. In A. M. Mendes (Orgs.), Psicodinâmica do trabalho: Teoria, métodos e pesquisas. Casa do Psicólogo.

Menezes, R. A. (2004). Em busca da boa morte: Antropologia dos cuidados paliativos. Garamond; Fiocruz. 224 p.

Milberg, A., Wåhlberg, R., Jakobsson, M., Olsson, E. C., Olsson, M., \& Friedrichsen, M. (2012). What is a 'secure base' when death is approaching?: A study applying attachment theory to adult patients' and family members' experiences of palliative home care. Psycho-oncol., 21(8), 886-895. https://doi.org/10.1002/pon.1982 
Minayo, M. C. S. (2013). O desafio do conhecimento: pesquisa qualitativa em saúde (13a ed.). Hucitec.

Ministério da Saúde. (2010). Ambiência (2a ed.). (Série B. Textos Básicos de Saúde). https://bvsms.saude.gov.br/bvs/publicacoes/ambiencia_2ed.pdf

Moreira, M. J. M. P. (2017). Precarização do trabalho no campo obstétrico: Percepções de enfermeiras. [Dissertação de Mestrado em Enfermagem, Universidade do Estado do Rio de Janeiro].

Oliveira, S. G., Quintana, A. M., Denardin-Budó, M. L., Bertolino, K. C. O., \& Kruse, M. H. L. (2011). A formação do enfermeiro frente às necessidades emergentes da terminalidade do indivíduo. Rev. enferm. UFSM, 1(1), 97-102. https://doi.org/10.5902/217976921996

Oliveira-Cardoso, E. A., Santos, M. A. (2017). Grupo de educação para a morte: Uma estratégia complementar à formação acadêmica do profissional de saúde. Psicol. cienc. prof., 37(2), 500-514. https://doi.org/10.1590/1982-3703002792015

Pedrosa, I. C. F., Corrêa, A. C. P., \& Mandú, E. N. T. (2011). Influências da infraestrutura de centros de saúde nas práticas profissionais: Percepções de enfermeiros. Ciênc. cuid. saúde, 10(1), 58-65. https://doi.org/10.4025/cienccuidsaude.v10i1.13288

Reigada, C., Pais-Ribeiro, J. L., Novellas, A., \& Pereira, J. L. (2014). O suporte à família em cuidados. Textos contexto, 13(1), 159-169. https://doi.org/10.15448/1677-9509.2014.1.16478

Rocha, F. L. R., Marziale, M. H. P., Carvalho, M. C., Cardeal Id, S. F., \& Campos, M. C. T. (2014). A cultura organizacional de um hospital público brasileiro. Rev. esc. enferm. USP, 48(2), 308-314. https://doi.org/10.1590/S0080-6234201400002000016

Rocha, P. K., Prado, M. L., Wal, M. L., \& Carraro, T. E. (2008). Cuidado e tecnologia: Aproximações através do modelo de cuidado. Rev. bras. enferm., 61(1), 113-116. https://doi.org/10.1590/S0034-71672008000100018

Rodrigues, I. G. (2009). Significados do trabalho em cuidados paliativos oncológicos domiciliar: Um estudo etnográfico. [Tese de Doutorado em Enfermagem, Universidade de São Paulo].

Roncarati, R., Camargo, R. M. P., Rossetto, E. G., \& Matsuo, T. (2003). Cuidados paliativos num hospital universitário de assistência terciária: uma necessidade? Semina cienc. biol. saude., 24(1), 37-48. http://dx.doi.org/10.5433/1679-0367.2003v24n1p37

Saar, S. R. C., \& Trevizan, M. A. (2007). Papéis profissionais de uma equipe de saúde: Visão de seus integrantes. Rev Latino-am Enferm., 15(1), 106-112. https://doi.org/10.1590/S0104-11692007000100016

Santos, T. A. (2012). Valor da força de trabalho da enfermeira. [Dissertação de Mestrado em Enfermagem, Universidade Federal da Bahia].

Silva, F. S., Pachemshy, L. R., \& Rodrigues, I. G. (2009). Percepção de enfermeiros intensivistas sobre distanásia em unidade de terapia intensiva. Rev. bras. ter. intensiva, 21(2), 148-154. https://doi.org/10.1590/S0103-507X2009000200006

Silva, G. (2015). Cuidados paliativos e subjetividade: Ações educativas sobre a vida e o morrer. [Tese de Doutorado em Educação, Universidade de Brasília].

Silva, K. S., \& Kruse, M. H. L. (2012). Em defesa da sociedade: A invenção dos cuidados paliativos e a produção de subjetividades. Rev. esc. enferm. USP, 46(2), 460-465. https://doi.org/10.1590/S0080-62342012000200026

Tavares, M. M., Gomes, A. M. T., Barbosa, D. J., Rocha, J. C. C. C., Bernardes, M. M. R., \& Thiengo, P. C. S. (2018). Espiritualidade e religiosidade no cotidiano da enfermagem hospitalar. Rev. enferm. UFPE on line, 12(4), 1097-1102. https://doi.org/10.5205/1981-8963-v12i4a234780p1097-1102-2018 